\title{
Light-Induced Iminyl Radicals: Generation and Synthetic Applications
}

\author{
Miguel A. Rodríguez \\ Departamento de Química, Unidad Asociada al C.S.I.C., Universidad de La Rioja \\ Spain
}

\section{Introduction}

The photochemistry of the carbon-nitrogen double bond was first explored in depth in the seventies (Padwa, 1977; Pratt, 1977). The low photochemical reactivity of this bond is due to the deactivation of the excited state of the imine by $E-Z$ isomerization processes, which do not have any synthetic utility because of their very low energy barrier for thermal conversion (Padwa \& Albrecht, 1974a, 1974b). However, the presence of an electronegative atom on the nitrogen opens up the field of reactivity. Studies on the energies of the N-O bonds in acyloximes show that this bond can easily undergo homolytic cleavage induced by ultraviolet light, a process that leads to iminyl radicals (Okada et al., 1969). The use of radicals has proven to be a useful tool in organic synthesis (Renaud \& Sibi, 2001; Togo, 2004; Zard, 2003). In particular, the cyclization of nitrogen-centred radicals, such as aminyl or iminyl radicals (Chart 1), is a valuable procedure for the preparation of nitrogen heterocycles (Fallis \& Brinza, 1997; Zard, 2008). It is therefore necessary to have effective methods for the production of these radicals.

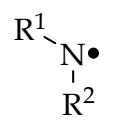

Aminyl<smiles>[R]C([R])=[W][V]</smiles>

Chart 1.

The direct way to create nitrogen radicals involves the homolytic cleavage of N-X bonds, while the addition of a radical to an unsaturated nitrogen functional group, such as a nitrile or an imine derivative, constitutes the most widely used indirect method. The cleavage of the bond may be triggered thermally or photochemically. This chapter focuses on the photochemical generation of iminyl radicals and the study of their reactivity. Firstly, the methods for the production of iminyl radicals will be reviewed and the reactivity of this species will be examined, highlighting its ability to be added to unsaturated systems, with particular emphasis on intramolecular cyclization reactions. At this point, the regioselectivity in the formation of five- and six-membered rings will be analysed. In terms of the course of these reactions, both experimental results and theoretical calculations on the reaction mechanism will be discussed. Finally, the last part of the chapter will be devoted to 
further synthetic applications of these reactions, particularly in the synthesis of different polycyclic heteroaromatic compounds and the preparation of natural products.

\section{Methods for the generation of iminyl radicals}

Different methods have been developed for the light-induced formation of iminyl radicals. The homolytic cleavage of $\mathrm{N}-\mathrm{X}$ bonds is a well known and widely used method for the production of this kind of radical, while the use of radical addition to nitriles is much more limited. These two alternatives will be described in detail below.

\subsection{Homolytic cleavage of $\mathrm{N}-\mathrm{X}$ bonds}

A range of different unsaturated nitrogen derivatives $(C=N-X)$ have been used as starting materials, where the heteroatom $X$ can be oxygen, nitrogen, sulfur or halogen. Of these, the most widely used approach is the cleavage of the $\mathrm{N}-\mathrm{O}$ bond and these systems will therefore be the starting point in this section.

\subsubsection{Cleavage of $\mathrm{N}-\mathrm{O}$ bonds}

The average bond energies of $\mathrm{C}=\mathrm{N}, \mathrm{N}-\mathrm{O}$ and $\mathrm{C}-\mathrm{O}$ bonds are 147, 53 and $86 \mathrm{kcal} / \mathrm{mol}$, respectively (Petrucci et al., 2011). The application of energy in the form of heat or light to $\mathrm{C}=\mathrm{N}-\mathrm{O}-\mathrm{C}$ structures should consistently fragment the N-O bond. To the best of my knowledge, the first reactions to involve the formation of iminyl radicals were the photolysis of oxadiazoles (Newman, 1968a, 1968b; Cantrell \& Haller, 1968; Mukai et al., 1969), benzo[c]isoxazole (Ogata et al., 1968), oxadiazolinone (Sauer \& Mayer, 1968) and aromatic oxime benzoates (Okada et al., 1969). In the latter case, dimerization of the radical occurred to give the major product (Scheme 1). The homolytic cleavage of similar $\mathrm{O}$-acyl aromatic ketoximes was also observed and this took place in the triplet excited state when the photolysis was conducted in the presence of triplet sensitizers (Yoshida et al., 1975).

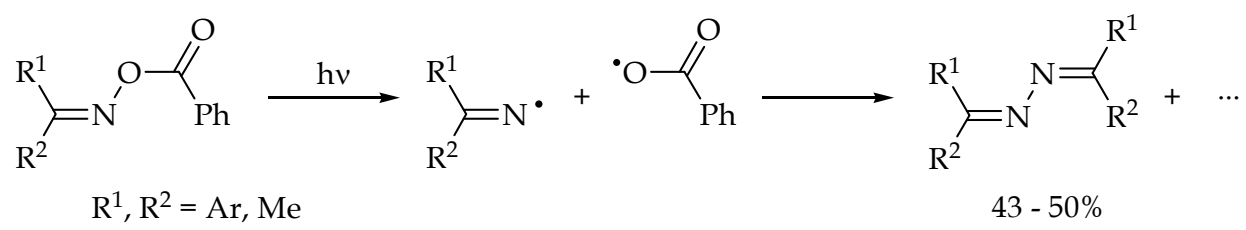

Scheme 1.

Since the nineties, interest in the photochemical generation of iminyl radicals has increased greatly. In a pioneering study by the group of Boivin \& Zard (Boivin et al., 1994), modified Barton esters, prepared from $O$-carboxymethyl derivatives of oximes, were irradiated to give an initial $\mathrm{N}-\mathrm{O}$ bond cleavage, which was followed by decarboxylation and loss of formaldehyde (Scheme 2), a process that provides a mild and very useful source of iminyl radicals. These radicals can evolve by subsequent intramolecular cyclization to give a fivemembered ring and subsequent transfer of a pyridylthiyl group from the starting Barton ester in the absence of an external trap. 


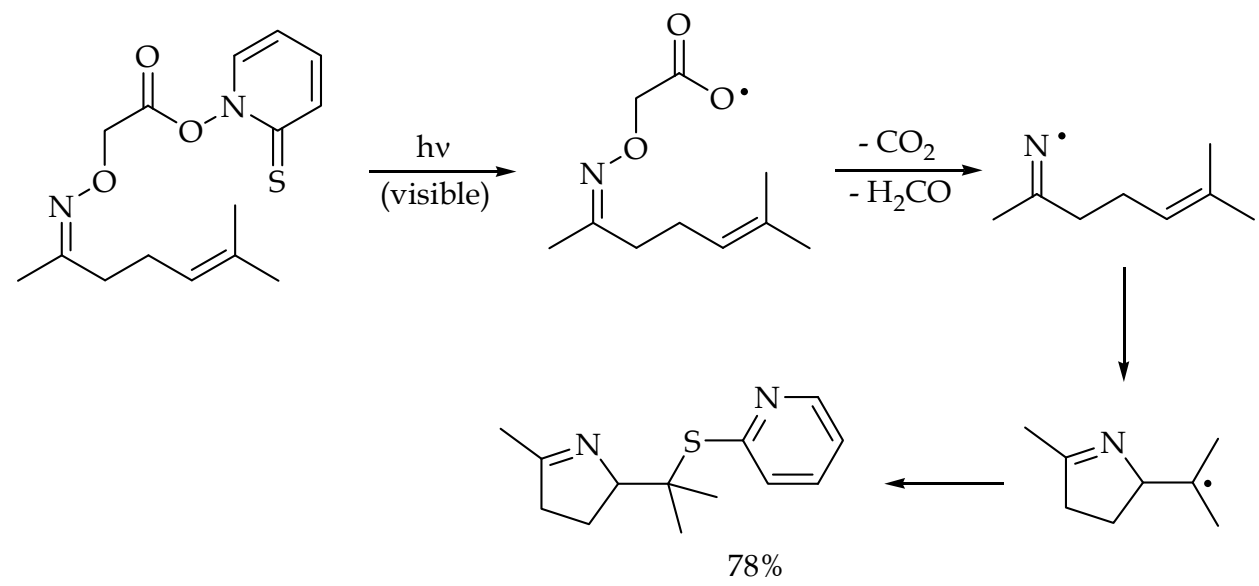

Scheme 2 .

A slight modification of this method allowed the homolytic substitution by iminyl radicals at selenium (Fong \& Schiesser, 1993). The photolysis of thiohydroxamic esters derived from the O-carboxymethyl oxime derivatives of 2-(benzylseleno)benzaldehyde gave 1,2benzoselenazoles in 70\% yield (Scheme 3). Similarly, Barton oxalate esters of oximes were used as starting materials. In this case, the formation of the iminyl radical takes place after a double decarboxylation (Boivin et al., 1994). An analogous thermal decomposition procedure involving decarboxylation and loss of formaldehyde to obtain an iminyl radical has been also described from peresters (Leardini et al., 2001).<smiles>N=Cc1ccccc1[Se]CCc1ccccc1</smiles>

Scheme 3 .

Although not used from a synthetic point of view, ketoxime diurethanes also lead to the formation of radicals (Hwang et al., 1999). Of greater applicability is the use of ketoxime xanthates (Gagosz \& Zard, 1999), which allow the preparation of a variety of substituted 1pyrrolines when the appropriate structure is irradiated (Scheme 4). The photoreaction has great versatility and gives yields between 72 and $88 \%$, which exceeds those of the thermal process (Gagosz \& Zard, 1999). The authors postulate that iminyl radicals generated by homolysis of the $\mathrm{N}-\mathrm{O}$ bond eventually escape from the solvent cage and then undergo cyclization. The resulting cyclised radical finally adds to the sulfur atom of the starting oxime xanthate, thus producing the cyclised dithiocarbonate and regenerating the iminyl species to propagate the chain. 
<smiles>C=CCC1CCCC/C1=N/OC(=S)SCCCCCCC1CCCCC1=NN</smiles>

Scheme 4 .

One alternative is to use oxime ethers as starting compounds. In a first paper, the group of Narasaka published the thermal treatment of $\gamma, \delta$-unsaturated $O$-(2,4-dinitrophenyl)oximes with sodium hydride and 3,4-methylenedioxyphenol, which gave 3,4-dihydro-2H-pyrroles after intramolecular cyclization (Uchiyama et al., 1998). The authors considered that this reaction proceeded with formation of an iminyl radical through an initial one-electron transfer from the sodium phenolate and expected that a similar electron transfer would occur on irradiation of the oxime ether in the presence of a sensitizer. Indeed, irradiation of $\gamma, \delta$-unsaturated $O$-aryloximes in the presence of 1,5 -dimethoxynaphthalene $(\mathrm{DMN})$ as a sensitizer led to 1-pyrrolines through cyclization of an iminyl radical (Mikami \& Narasaka, 2000; 2001). The reaction was carried out in the presence of 1,4-cyclohexadiene (CHD) in order to trap the radical resulting from the intramolecular addition to the alkene (Scheme 5).

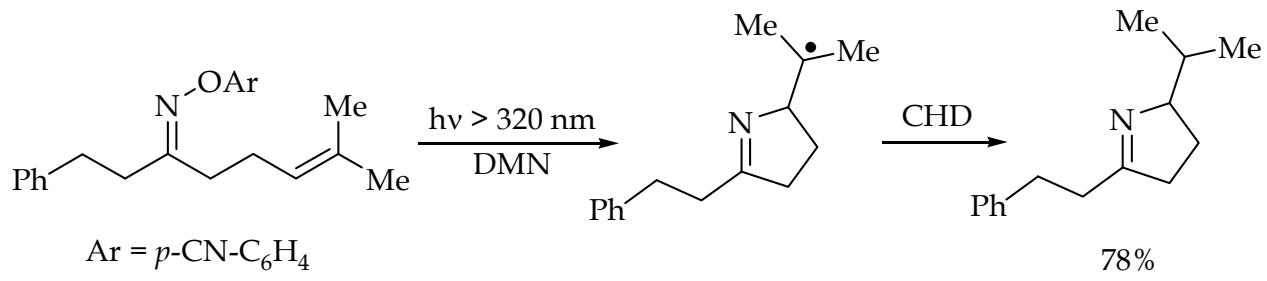

Scheme 5 .

The mechanistic aspects of the photosensitized reactions of a series of oxime ethers have been studied by steady-state and laser flash photolysis methods (de Lijser \& Tsai, 2004; de Lijser et al., 2007). On the basis of these experiments, the formation of iminyl radicals is rationalized. On the other hand, Narasaka's group also studied the effect of substituting an ether oxime by an acetate oxime (Kitamura et al., 2005; Kitamura \& Narasaka, 2008). The sensitized photoreaction in acetonitrile again led to the formation of five-membered rings in good yields (Scheme 6).<smiles>C=CCC/C(=N\OC(C)=O)c1ccccc1</smiles>

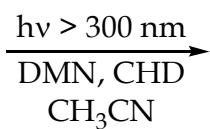<smiles>CC1CCC(c2ccccc2)=N1</smiles>

Scheme 6 . 
The formation of six-membered heterocyclic rings by intramolecular cyclization between an iminyl radical and an olefin was first reported by Rodríguez and co-workers (Alonso et al., 2006). Direct irradiation of 2-vinylbenzaldehyde $\mathrm{O}$-acetyloximes induced $\mathrm{N}-\mathrm{O}$ bond cleavage and led to the formation of an iminyl radical, which was able to add to a vinyl group to give isoquinolines after aromatisation through the formal loss of a hydrogen atom (Scheme 7). Analysis of the Stern-Volmer plots (Turro, 1991) for the quenching of the photoreactivity of acyloximes in the presence of common triplet-state quenchers shows that both excited states, singlet and triplet, undergo the same N-O fracture (Alonso et al., 2008). Direct and sensitized laser experiments also led to the same conclusion (Lalevée et al., 2002). According to ab initio molecular orbital calculations on the singlet excited states of acyloximes, the oscillator strength for the $n-\pi^{*} S_{0} \rightarrow S_{1}$ transition should be 0.014 , with a $\lambda_{\max }$ of $233 \mathrm{~nm}$, while the $\pi-\pi^{*} S_{0} \rightarrow S_{2}$ transition should have an oscillator strength of 0.2 , with a $\lambda_{\max }$ of $212 \mathrm{~nm}$, which indicate that $S_{2}$ is the spectroscopic state while $S_{1}$ is an excited dark state. Relaxation from $\mathrm{S}_{2}$ leads directly to $\mathrm{N}-\mathrm{O}$ bond cleavage due to the coupling between the imine $\pi^{*}$ and the $\sigma^{*} \mathrm{~N}-\mathrm{O}$ orbitals (Alonso et al., 2008).

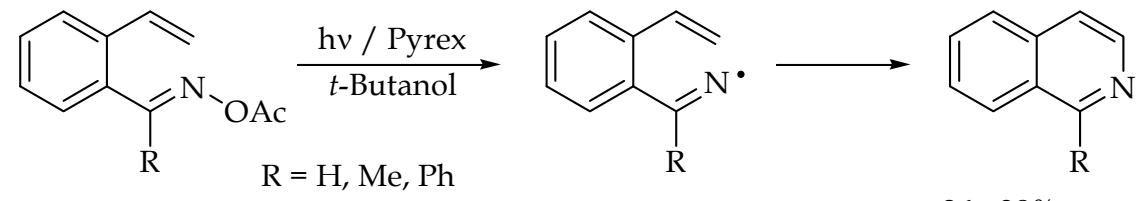

$26-38 \%$

Scheme 7.

The reaction is also effective for carbon-carbon triple bonds (Alonso et al., 2006). In the intramolecular version, the addition of a nitrogen-centred radical should generate an isoquinolyl radical, which may evolve by atom abstraction since the use of 2-propanol- $d_{7}$ as solvent led to 4-deuteroquinoline, while the use of methanol- $d_{1}$ led to nondeuterated isoquinoline (Scheme 8).

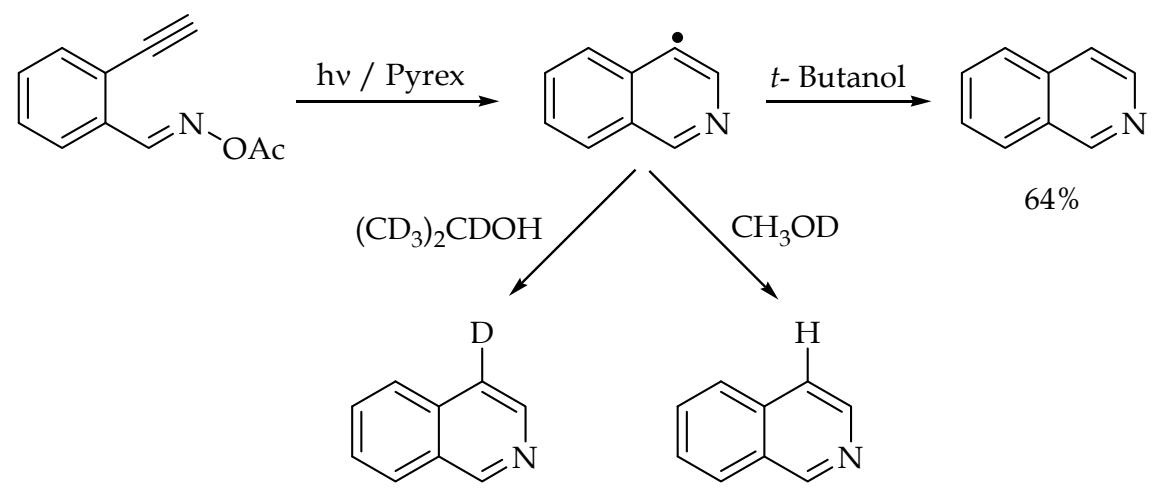

Scheme 8 .

The light-induced intermolecular attack of the iminyl radical on a carbon-carbon triple bond has also been reported (Alonso et al., 2006). As shown in Scheme 9, irradiation of 
benzophenone $O$-acetyloxime in the presence of tolane or dimethyl acetylenedicarboxylate induces a tandem (cascade) process of intermolecular addition/intramolecular cyclization with formation of isoquinoline in good yields.<smiles>CC(=O)ON=C(c1ccccc1)c1ccccc1</smiles>

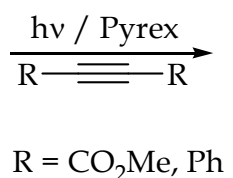<smiles>[R]C=C([R])N=C(c1ccccc1)c1ccccc1</smiles><smiles>[R]c1nc(-c2ccccc2)c2ccccc2c1[R]</smiles>

$74-76 \%$

Scheme 9 .

Similarly, the iminyl radicals generated by the action of UV light are capable of reacting with alkynyl Fischer carbenes (Blanco-Lomas et al., 2011). The reaction led to the formation of the new carbene complex together with another product, identified as a seven-membered compound (Scheme 10). Based on mechanistic studies, it is proposed that the iminyl radical would attack the alkynyl carbene at the alkynyl carbon (1,4-addition) to form the carbene complex, while 1,2-addition at the carbene carbon should lead to the cyclic structure.

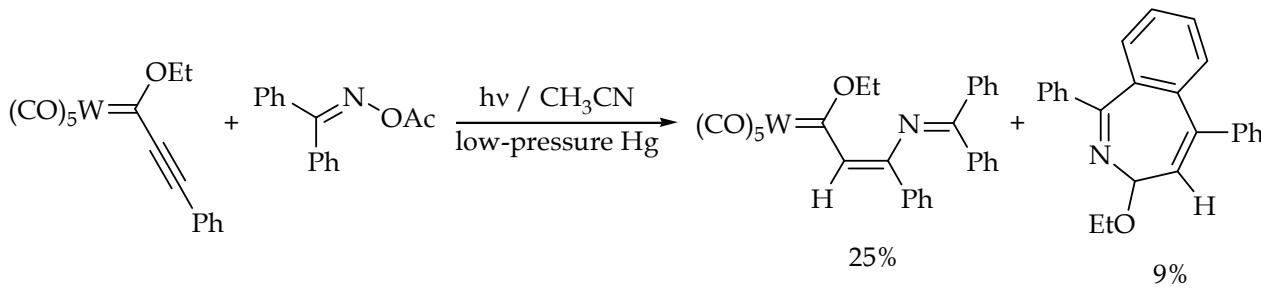

Scheme 10.

An aromatic ring can also be used as an unsaturated system. This kind of attack by iminyl radicals was previously observed when the photolysis of aromatic ketone $O$-acyloximes took place in aromatic solvents and this process involves a homolytic aromatic substitution (Sakuragi et al., 1976). Starting from appropriately substituted oximes (Scheme 11), different phenanthridines were obtained in good to excellent yields after intramolecular cyclization onto a phenyl ring followed by rearomatisation (Alonso et al., 2006). In the case of aldehyde $O$-acyloxime $(\mathrm{R}=\mathrm{H})$ the iminyl radical partially decomposed into a nitrile (Bird et al., 1976).

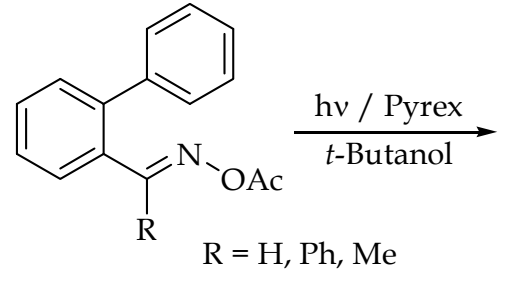<smiles>[R]c1nc2ccccc2c2ccccc12</smiles>

$40-91 \%$

Scheme 11. 
Finally, dioxime oxalates are also precursors of iminyl radicals. Irradiation of these compounds in the presence of 4-methoxyacetophenone as a sensitizer allowed the preparation of dihydropyrroles and phenanthridines (Portela-Cubillo et al., 2008).

\subsubsection{Cleavage of $\mathrm{N}-\mathrm{N}, \mathrm{N}-\mathrm{S}$ and $\mathrm{N}-\mathrm{Br}$ bonds}

Although N-N bonds are generally stronger than N-O bonds, homolysis of $\mathrm{N}-\mathrm{N}$ bonds also offers an attractive alternative for the generation of iminyl radicals. Irradiation of hydrazones led to the formation of azines (Takeuchi et al., 1972) or, in the presence of a good hydrogen donor, to a mixture of amines and imines (Binkley, 1970) after N-N bond scission. Iminyl radicals are also formed by the reaction of photochemically generated tert-butoxyl radicals with primary or secondary alkyl azides (Roberts \& Winter, 1979). However, these procedures are of little synthetic utility. In contrast, as shown in Scheme 12, irradiation with a sunlamp of readily accessible thiocarbazone derivatives in the presence of catalytic amounts of hexabutylditin provides adducts that arise from subsequent intramolecular cyclization of an iminyl radical and transfer of an iminodithiocarbonate group (CallierDublanchet et al., 1997). The cleavage of the $\mathrm{N}-\mathrm{N}$ bond seems to be relatively slow and the optimum substituent on the thiocarbazone moiety has yet to be determined.<smiles>COP(=O)(OC)C(CC1C=CCC1)=NN(C(=S)S(C)(C)C)c1ccccc1</smiles><smiles>COP(=O)(OC)C1=N[C@H]2C(CC[C@@H]2SC(N)=[PH2])C1</smiles>

Scheme 12.

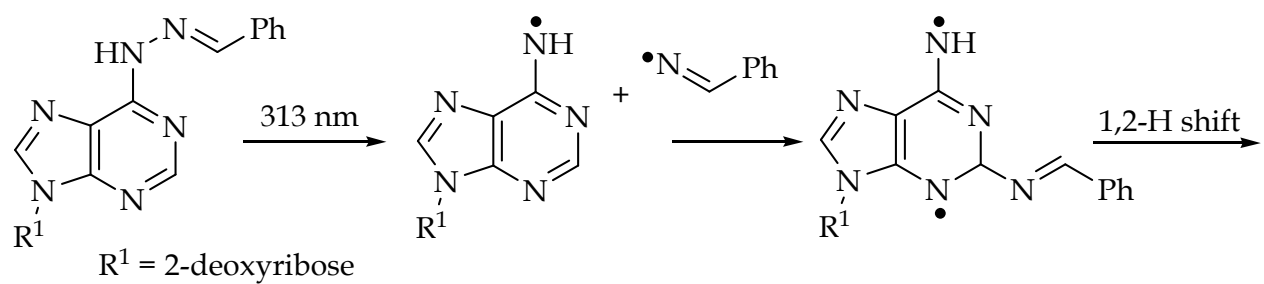<smiles></smiles>

Scheme 13.

Interest in the photolytic cleavage of the nitrogen-nitrogen single bond in phenylhydrazones has increased in recent years because results from systematic studies indicate that both the aminyl and the iminyl radicals have DNA-cleaving ability (Hwu et al., 2004). Upon UV 
photolysis, modified 2'-deoxyadenosine containing a photoactive phenylhydrazone moiety undergoes efficient homolytic cleavage to give aminyl and iminyl radicals (Kuttappan-Nair et al., 2010). Both radicals evolve by recombination as the main pathway (Scheme 13). Alternatively, it is reasonable to propose that these radicals react with other DNA base moieties, leading to intra- and interstrand cross-linking.

Although thermal reactions are more commonly used (Zard, 2008; Esker \& Newcomb, 1993), sulfanyl imines can also be employed as precursors of iminyl radicals in photochemical reactions (Guindon et al., 2001). Irradiation of benzothiazolylsulfanylimines induces the cleavage of the N-S bond and facilities a tandem process of intramolecular iminyl radical cyclofunctionalization/hydrogen transfer to afford syn-anti 1-pyrrolines with high levels of 1,2-induction in both steps (Scheme 14).<smiles></smiles>

AIBN $=$ Azobisisobutylonitrile<smiles>[R]C1CC=N[C@H]1C(C)C(=O)OCC</smiles>

\begin{tabular}{ccc}
$\mathrm{R}$ & syn:anti & Yield (\%) \\
\hline $\mathrm{H}$ & $1: 9$ & 83 \\
$\mathrm{Me}$ & $1: 16$ & 84 \\
$\mathrm{OMe}$ & $1: 7$ & 78
\end{tabular}

Scheme 14 .<smiles>[R]CCC=C[R1]#[R]C1=NC(C)CC1</smiles>

Scheme 15.

The generation of alkoxyiminyl radicals can be addressed by photolysis of $N$-bromo imidates (Glober et al., 1993). These radicals can undergo exo-1,5 and exo-1,6 cyclization onto 
olefins on the $O$-alkyl side chains, to give 4,5-dihydrooxazoles or 5,6-dihydro- $4 H$-1,3oxazines, respectively, or exo-1,5 cyclization onto an olefin on the iminyl side chain, to yield 2-alkoxy-1-pyrrolines (Scheme 15). The experimental results indicate that dihydrooxazole formation is more favourable than cyclization to 1-pyrrolines, a finding that has been rationalized by semiempirical MNDO molecular orbital calculations.

\subsection{Addition of a radical to an unsaturated nitrogen derivative}

In the previous section, direct methods of generating an iminyl radical by homolytic cleavage of an $\mathrm{N}-\mathrm{X}$ bond have been examined. An alternative to these methods is the photochemical formation of another radical and subsequent addition to an unsaturated nitrogen derivative, such as an azide or a nitrile. This indirect approach was first reported by Roberts's group (Cooper et al., 1977). A photochemically generated tert-butoxyl radical reacted with primary or secondary alkyl azides to produce iminyl radicals (Scheme 16), which ultimately yielded a ketone after hydrolysis.

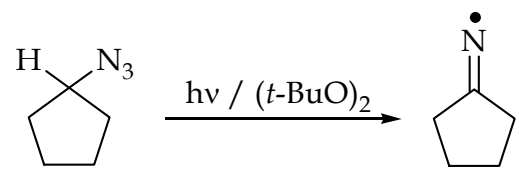

Scheme 16.

5-Bromovaleronitrile was used to establish the rate constant of cyclization of the 4cyanobutyl radical to the cyclopentiminyl radical (Griller et al., 1979), as determined by kinetic measurements using electron paramagnetic resonance (EPR) spectroscopy, and this was found to be $k_{\mathrm{c}} \mathrm{C} \equiv \mathrm{N}=4.0 \times 10^{4} \mathrm{~s}^{-1}$ at $80^{\circ} \mathrm{C}$, almost an order of magnitude slower than the analogous 5-hexynyl radical $\left(k_{\mathrm{c}} \mathrm{C} \equiv \mathrm{C}=1.2 \times 10^{5} \mathrm{~s}^{-1}\right.$ at $\left.80^{\circ} \mathrm{C}\right)$. The reaction is initiated by photolysis of hexabutylditin (Scheme 17).

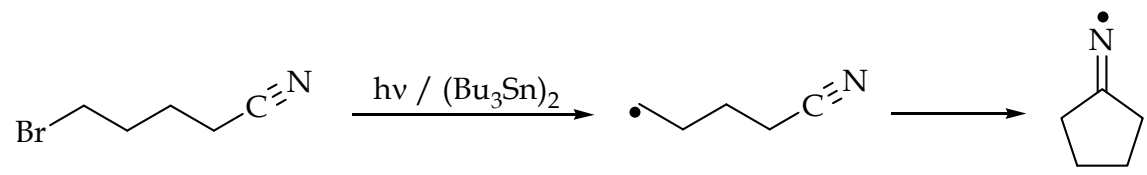

Scheme 17.

With respect to intermolecular reactions, a couple of examples have been reported where photochemically generated radicals add to acetonitrile (Engel et al., 1987; de Lijser \& Arnold, 1997). Carbon-centred radicals prefer to add to the carbon of the nitrile to give the iminyl radical (de Lijser \& Arnold, 1998), a preference that has been rationalized by a timeresolved infrared study on the photochemistry of O-fluoroformyl-9-fluorenone oxime in acetonitrile solution and by ab initio molecular orbital calculations (Bucher et al., 2006). In addition to the N-O bond cleavage, upon laser flash photolysis $(266 \mathrm{~nm})$ the short-lived transient fluoroformyl radical and the transient iminyl radical were detected (Scheme 18).

Boryl radicals also add to nitriles. Photochemically formed tert-butoxyl radicals were capable of abstracting hydrogen from borohydride anions to form a borane radical anion, 
which added to cyanides to give iminyl radical adducts (Giles \& Roberts, 1983). Similarly, these tert-butoxyl radicals reacted with primary amine-boranes to give amine-boryl radicals, which can be intercepted by addition to the CN group (Kirwan \& Roberts, 1989).<smiles>CC(=O)C(=N)F</smiles>

Scheme 18.

\section{Characterization, kinetic data and calculations}

In order to perform an adequate characterization of iminyl radicals, it is necessary to have valid precursors. In this sense, oxime esters seem to be suitable substrates for these experiments. The photochemistry of 9-fluorenone oxime phenylglyoxilate was investigated by laser flash photolysis at $355 \mathrm{~nm}$, using time-resolved EPR spectroscopy (Kolano et al., 2004). The first step in the reaction would be cleavage of the N-O bond to give, initially, the 9-fluorenoneiminyl radical and the benzoylcarbonyloxy radical (Scheme 19). This process led to the detection, among others, of a set of transient signals, a 1:1:1 triplet centred at $3455.7 \mathrm{G}\left(J_{\mathrm{N}}=9.7 \mathrm{G}\right)$ attributed to the iminyl radical. Previous hyperfine splitting values obtained for iminyl radicals were in the range 9.1 to $10.3 \mathrm{G}$ (Griller et al., 1974).
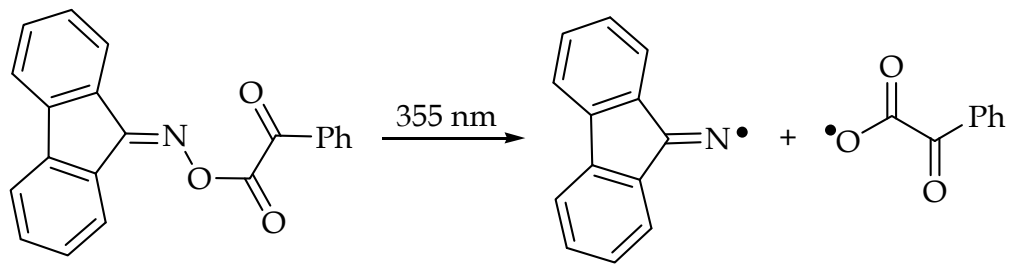

Scheme 19.

The group of Walton has devoted a great deal of attention to iminyl radicals. They used EPR spectroscopy to detect and characterize several N-centred radicals (McCarroll \& Walton, 2000). Of particular interest is the study on the pentenyliminyl radicals (Portela-Cubillo et al., 2009). These radicals selectively closed in the 5-exo mode, irrespective of the substitution pattern around the $\mathrm{C}=\mathrm{C}$ double bond of the pentenyl chain (Scheme 20). DFT computations have been used to model the experimental results obtained. The rate constant for the parent compound $\left(\mathrm{R}^{1}=\mathrm{Ph} ; \mathrm{R}^{2}=\mathrm{R}^{3}=\mathrm{R}^{4}=\mathrm{H}\right)$ was $k_{\mathrm{c}}{ }^{5-e x o}=8.8 \times 10^{3} \mathrm{~s}^{-1}$ at $27^{\circ} \mathrm{C}$, while the presence of two phenyl groups at the end of the $\mathrm{C}=\mathrm{C}$ bond $\left(\mathrm{R}^{1}=\mathrm{Me} ; \mathrm{R}^{2}=\mathrm{H} ; \mathrm{R}^{3}=\mathrm{R}^{4}=\mathrm{Ph}\right)$ gave rise to a cyclization rate constant of $k_{\mathrm{c}}{ }^{5-x x}=2.2 \times 10^{6} \mathrm{~s}^{-1}$ at $25^{\circ} \mathrm{C}$ (Le Tadic-Biadatti et al., 1997). The rate of cyclization is slower for an iminyl with two $\mathrm{H}$ atoms at the terminus of the $\mathrm{C}=\mathrm{C}$ double bond $\left(\mathrm{R}^{3}=\mathrm{R}^{4}=\mathrm{H}\right)$ than that with two phenyl groups $\left(\mathrm{R}^{3}=\mathrm{R}^{4}=\mathrm{Ph}\right)$, probably due to the higher stability of the phenyl conjugated $\mathrm{C}$-centred radical formed for the later during the cyclization reaction. 

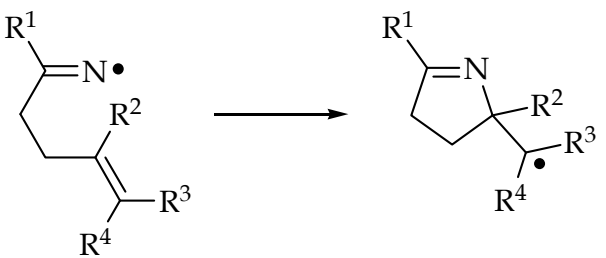

Scheme 20 .

The rate constants of other processes involving radicals have also been measured. For example, in the bimolecular combination reactions to form the corresponding azides, in some cases values close to the diffusion controlled limit have been measured, $k^{2} \sim 3 \times 10^{8} \mathrm{M}^{-1}$ $\mathrm{s}^{-1}$ at $-28^{\circ} \mathrm{C}$ (Portela-Cubillo et al., 2009), while others range between $10^{2}$ and $10^{9} \mathrm{M}^{-1} \mathrm{~s}^{-1}$ at -35 ${ }^{\circ} \mathrm{C}$ depending on steric factors (Griller et al., 1974). Iminyl radicals also abstract hydrogen from different species. Specifically, the rate constants for the reaction of the iminyl radical shown in Scheme $20\left(\mathrm{R}^{1}=\mathrm{Me} ; \mathrm{R}^{2}=\mathrm{H} ; \mathrm{R}^{3}=\mathrm{R}^{4}=\mathrm{Ph}\right)$ with thiophenols has been estimated at $k^{\mathrm{H}} \sim 10^{7} \mathrm{M}^{-1} \mathrm{~s}^{-1}$ at $25^{\circ} \mathrm{C}$ (Le Tadic-Biadatti et al., 1997).

Iminyl radicals have also been studied by theoretical DFT calculations. Since these species could evolve through cyclization to the five- or six-membered rings, the course of the ring formation has been calculated (Alonso et al., 2008). The choice of B3PW91 was made on the basis of previous results where this functional proved to give satisfactory results in radical chemistry (Pace et al., 2006; Pinter et al., 2007). As can be seen from Table 1 and Figure 1, the calculated relative free energies for the transition states of the cyclization to the five- and six-membered ring when no other factor is present are 12.6 and 16.0 $\mathrm{kcal} / \mathrm{mol}$, respectively, at the B3PW91/6-31+G* level, which indicates a preference for the formation of the 1-pyrroline ring. The presence of an aromatic ring as a spacer makes these values 6.4 and $5.6 \mathrm{kcal} / \mathrm{mol}$, respectively, and indicates a small preference for the construction of the six-membered ring (Table 1). These predictions were corroborated by experimental results.

\begin{tabular}{|c|c|c|c|c|}
\hline & 0.0 & 0.0 & 0.0 & 0.0 \\
\hline Iminyl Radical & 0.0 & 16.0 & 6.4 & 5.6 \\
\hline Transition State & 12.6 & -7.6 & -10.6 & -27.7 \\
\hline Product & -5.2 & \\
\hline
\end{tabular}

Table 1 . Free energies $(\Delta G, \mathrm{kcal} / \mathrm{mol})$ for the cyclization step to five- or six-membered rings, relative to the corresponding iminyl radical, at the B3PW91/6-31+ $\mathrm{G}^{*}$ level

DFT calculated structures and energies have also been used to understand the influence of some substituents on the reactivity of iminyl radicals (Alonso et al., 2010). The most significant is the reduction of the energy barrier, from 14.6 to $13.2 \mathrm{kcal} / \mathrm{mol}$ at the B3PW91/6-31G* level, when a methyl group is located on the iminic carbon (Figure 2). This change is probably due to electronic effects. 


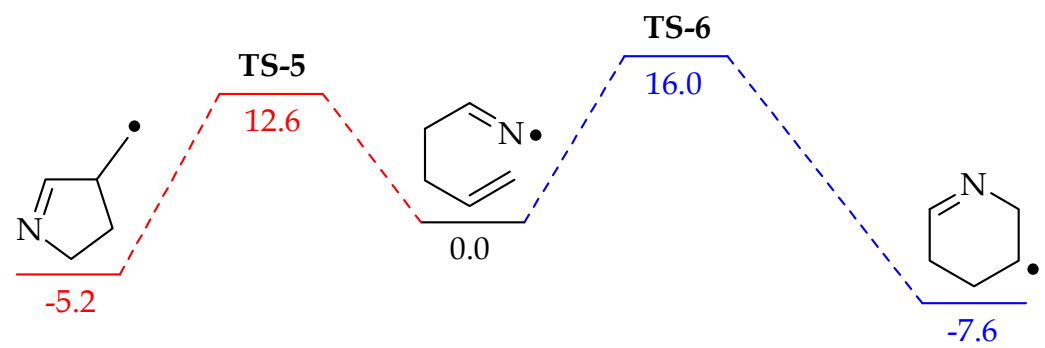

Fig. 1. Free energy diagram $(\Delta G, \mathrm{kcal} / \mathrm{mol})$ for the cyclization of the simplest iminyl radical, at the B3PW91/6-31+G* level<smiles>[R]C(=[NH2+])c1c(-c2ccccc2)[nH]c2ccccc12</smiles>

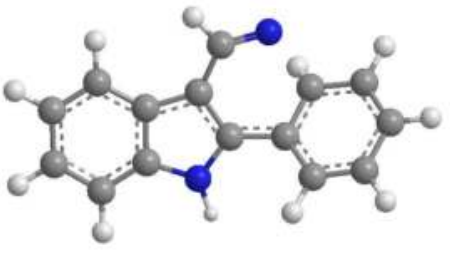

$\mathrm{R}=\mathrm{H}, 14.6 \mathrm{kcal} / \mathrm{mol}$

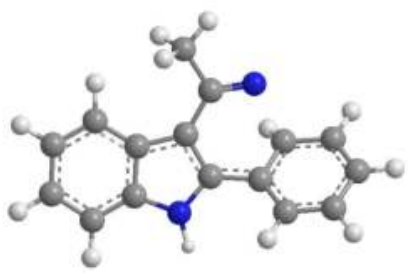

$\mathrm{R}=\mathrm{Me}, 13.2 \mathrm{kcal} / \mathrm{mol}$

Fig. 2. DFT optimised structures and energy barriers, relative to the corresponding iminyl radical, at the B3PW91/6-31G* level

\section{Preparation of polycyclic heteroaromatic compounds and natural products}

Direct irradiation of $O$-acyloximes has also been employed for the preparation of several polycyclic heteroaromatic compounds. As shown in Scheme 21, the use of a combination of reagents with five- and six-membered rings and cyclization of the intermediate iminyl radicals onto phenyl, thiophenyl or pyridinyl rings led to a variety of fused rings with different heteroatoms on the structure in good to excellent yields (48 to 90\%) (Alonso et al., 2010). Thus, 2H-pyrazolo[4,3-c]quinoline, thieno[3,2-c]isoquinoline and benzo[c][1,7] naphthyridine derivatives have been prepared.

The versatility of this methodology has been exploited in the preparation of some interesting natural products. On using the appropriate structure (Scheme 22), direct irradiation of $O$ acyloximes allowed the preparation of several phenanthridine derivatives (Alonso et al., 2010), such as the alkaloid trisphaeridine $\left(\mathrm{R}^{1}, \mathrm{R}^{2}=\mathrm{OCH}_{2} \mathrm{O} ; \mathrm{R}^{3}=\mathrm{H}\right)$ or the vasconine precursor $\left(\mathrm{R}^{1}=\mathrm{R}^{2}=\mathrm{OCH}_{3} ; \mathrm{R}^{3}=\mathrm{CH}_{2} \mathrm{CH}_{2} \mathrm{OH}\right)$, which can also be used to obtain assoanine, oxoassoanine and pratosine (Rosa et al., 1997). Trisphaeridine was also prepared in 59\% 
yield by irradiation of the corresponding dioxime oxalate in the presence of 4methoxyacetophenone as a photosensitizer (Portela-Cubillo et al., 2008).

An indirect method to form iminyl radicals by addition of a radical to a nitrile has been used to synthesize heteropolycycles. The process involves a cascade reaction from a photochemically generated radical. The formation of a tetracyclic heteroarene initiated by irradiation of an aromatic disulfide, with cleavage of an S-S bond, is shown in Scheme 23. The intermolecular addition of the sulfanyl radical to isonitriles gave an imidoyl radical, which was able to add to a nitrile to provide an iminyl radical that cyclizes to complete the cascade reaction (Camaggi et al., 1998; Nanni et al., 2000).<smiles>CC(=O)O/N=C(/C)c1cn(C)nc1-c1ccccc1</smiles><smiles>CC(=O)O/N=C/c1ccccc1-c1cccs1</smiles><smiles>CC(=O)O/N=C(\C)c1ccccc1-c1ccncc1</smiles>

Scheme 21.<smiles>[R]c1cccc(-c2cc([R4])c([R])cc2/C=N/OC(C)=O)c1</smiles><smiles>[R]c1cc2cnc3c([R])cccc3c2cc1[R]</smiles>

$39-53 \%$

Scheme 22 . 


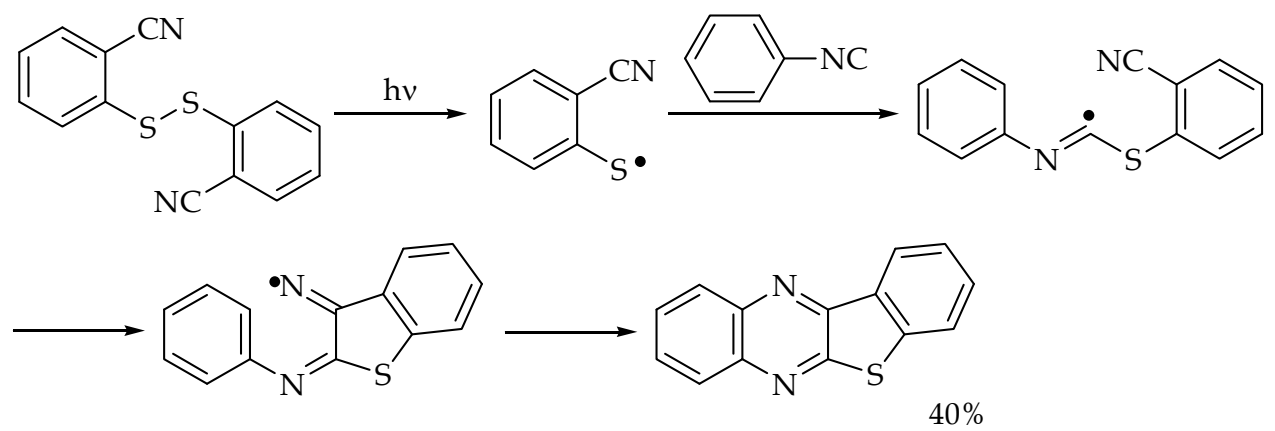

Scheme 23 .

The preparation of rings A-D of the alkaloids camptothecin and mappicine has been achieved in good yield using this protocol (Bowman et al., 2001; 2002). After light-induced cleavage of hexamethylditin and abstraction of the iodine atom to give a vinyl radical, subsequent 5-exo cyclization onto the nitrile and 6-exo cyclization of iminyl radical followed by aromatisation led to the four ring skeleton (Scheme 24).

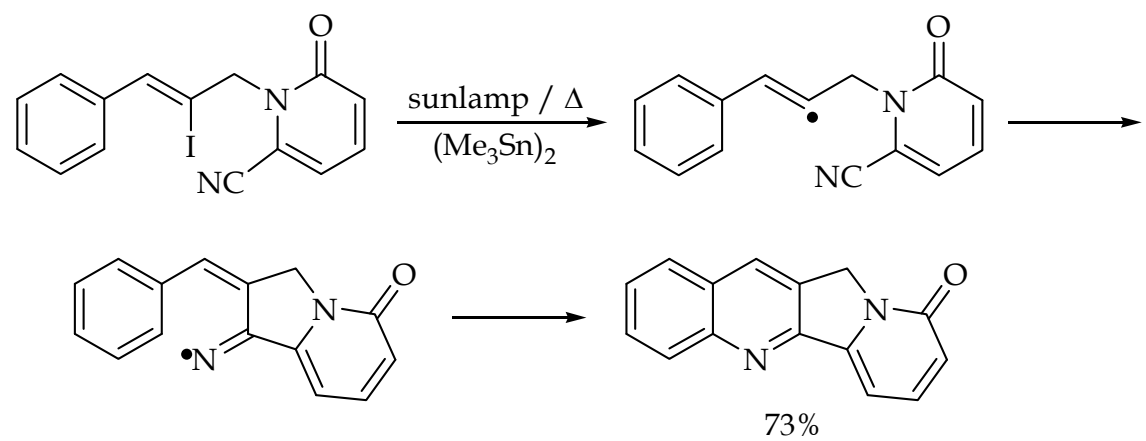

Scheme 24 . 
<smiles>N#Cc1nc2ccccc2c(=O)n1C/C(I)=C/c1ccccc1</smiles><smiles>N#CN(Cc1cc2ccccc2nc1I)C(=O)c1ccccc1</smiles>

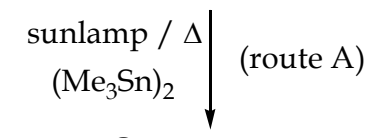
$\begin{gathered}\text { sunlamp } / \Delta \\ \left(\mathrm{Bu}_{3} \mathrm{Sn}\right)_{2}\end{gathered} \mid$ (route B)<smiles>N#Cc1nc2ccccc2c(=O)n1C/C=C/c1ccccc1</smiles><smiles>N#CN(Cc1cnc2ccccc2c1)C(=O)c1ccccc1</smiles><smiles>N=C1/C(=C\c2ccccc2)Cn2c1nc1ccccc1c2=O</smiles><smiles>CCC</smiles><smiles>N=C1c2nc3ccccc3cc2CN1C(=O)c1ccccc1</smiles>

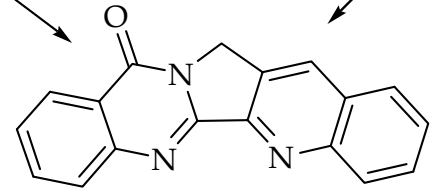

Scheme 25 .

The biologically active alkaloid luotonin A has been obtained using cascade radical cyclization via an iminyl radical from 4-oxo-3,4-dihydroquinazoline-2-carbonitrile (Bowman et al., 2005). In a similar way, the vinyl radical attacked the cyano group and the resulting iminyl radical cyclized to the alkaloid (Scheme 25, route A). More recently, an alternative cyclization cascade process has been described for the preparation of luotonin A (Servais et al., 2007). As shown in Scheme 25 (route B), under radical conditions the pyrroloquinazoline skeleton is created from $\mathrm{N}$-acyl-N-(2-iodobenzyl)cyanamide.

\section{Conclusion}

The photochemical generation of iminyl radicals can be performed in a direct way, which involves the homolytic cleavage of $\mathrm{N}-\mathrm{X}$ bonds, or by an indirect method, which involves the addition of a radical to an unsaturated nitrogen functional group, such as an azide or a nitrile. Regarding the reactivity of this kind of radical, its ability to be added to unsaturated systems (double and triple bonds, aromatic and heteroaromatic compounds) has been 
revealed. The addition reaction can occur with the formation of five- or six-membered rings. The ease with which these processes take place allows their use in further synthetic applications, particularly in the synthesis of different polycyclic heteroaromatic compounds and in the preparation of natural products.

\section{Acknowledgment}

Financial support from the Ministerio de Ciencia e Innovación of Spain (CTQ2011-24800) and Universidad de La Rioja (API11/20) is gratefully acknowledged.

\section{References}

Alonso, R.; Campos, P. J.; García, B. \& Rodríguez, M. A. (2006). Org. Lett., 8, 3521

Alonso, R.; Campos, P. J.; Rodríguez, M. A. \& Sampedro, D. (2008). J. Org. Chem., 73, 2234

Alonso, R.; Campos, P. J.; Caballero, A. \& Rodríguez, M. A. (2010). Tetrahedron, 66, 8828

Binkley, R. W. (1970). J. Org. Chem., 35, 2796

Bird, K. J.; Chan, A. W. K. \& Crow, W. D. (1976). Aus. J. Chem., 29, 2281

Blanco-Lomas, M.; Caballero, A.; Campos, P. J.; González, H. F.; López-Sola, S.; RivadoCasas, L.; Rodríguez, M. A. \& Sampedro, D. (2011). Organometallics, 30, 3677

Boivin, J.; Fouquet, E.; Schiano, A.-M. \& Zard, S. Z. (1994). Tetrahedron, 50, 1769

Bowman, W. R.; Bridge, C. F.; Cloonan, M. O. \& Leach, D. C. (2001). Synlett, 765

Bowman, W. R.; Bridge, C. F.; Brookes, P.; Cloonan, M. O. \& Leach, D. C. (2002). J. Chem. Soc., Perkin Trans. 1, 58

Bowman, W. R.; Cloonan, M. O.; Fletcher, A. J. \& Stein, T. (2005). Org. Biomol. Chem., 3, 1460

Bucher, G.; Kolano, C.; Schade, O. \& Sander, W. (2006). J. Org. Chem., 71, 2135

Callier-Dublanchet, A.-C.; Quiclet-Sire, B. \& Zard, S. Z. (1997). Tetrahedron Lett., 38, 2463

Camaggi, C. M.; Leardini, R.; Nanni, D. \& Zanardi, G. (1998). Tetrahedron, 54, 5587

Cantrell, T. S. \& Haller, W. S. (1968). Chem. Commun., 977

Cooper, J. W.; Roberts, B. P. \& Winter, J. N. (1977). J. Chem. Soc., Chem. Commun., 320

de Lijser, H. J. P. \& Arnold, D. R. (1997). J. Chem. Soc., Perkin Trans. 2, 1369

de Lijser, H. J. P. \& Arnold, D. R. (1998). J. Org. Chem., 69, 3057

de Lijser, H. J. P. \& Tsai, C.-K. (2004). J. Phys. Chem., 102, 5592

de Lijser, H. J. P.; Rangel, N. A.; Tetalman, M. A. \& Tsai, C.-K. (2007). J. Org. Chem., 72, 3057

Engel, P. S.; Lee, W.-K.; Marschke, G. E. \& Shine, H. J. (1987). J. Org. Chem., 52, 2813

Esker, J. L. \& Newcomb, M. (1993). Adv. Heterocycl. Chem., 58, 1

Fallis, A. G. \& Brinza, I. M. (1997). Tetrahedron, 53, 17543

Fong, M. C. \& Schiesser, C. H. (1993). Tetrahedron Lett., 34, 4347

Gagosz, F. \& Zard, S. Z. (1999). Synlett, 1978

Giles, J. R. M. \& Roberts, B. P. (1983). J. Chem. Soc., Perkin Trans. 2, 743

Glober, S. A.; Hammond, G. P.; Harman, D. G.; Mills, J. G. \& Rowbottom, C. A. (1993). Aus. J. Chem., 46, 1213 
Griller, D.; Mendenhall, G. D.; Van Hoof, W. \& Ingold, K. U. (1974). J. Am. Chem. Soc., 96, 6068

Griller, D.; Schmid, P. \& Ingold, K. U. (1979). Can. J. Chem., 57, 831

Guindon, Y.; Guérin, B. \& Landry, S. R. (2001). Org. Lett., 3, 2293

Hwang, H.; Jang, D.-J. \& Chae, K. H. (1999). J. Photochem. Photobiol. A: Chemistry, 126, 37

Hwu, J. R.; Lin, C. C.; Chuang, S. H.; King, K. Y.; Su, T.-R. \& Tsay, S.-C. (2004). Bioorg. Med. Chem., 12, 2509

Kirwan, J. N. \& Roberts, B. P. (1989). J. Chem. Soc., Perkin Trans. 2, 539

Kitamura, M.; Mori, Y. \& Narasaka, K. (2005). Tetrahedron Lett., 46, 2373

Kitamura, M. \& Narasaka, K. (2008). Bull. Chem. Soc. Japan, 81, 539

Kolano, C.; Bucher, G.; Wenk, H. H.; Jäger, M.; Schade, O. \& Sander, W. (2004). J. Phys. Org. Chem., 17, 207

Kuttappan-Nair, V.; Samson-Thibault \& Wagner, J. R. (2010). Chem. Res. Toxicol., 23, 48

Lalevée, J.; Allonas, X.; Fouassier, J. P.; Tachi, H.; Izumitani, A.; Shirai, M. \& Tsunooka, M. (2002). J. Photochem. Photobiol. A: Chemistry, 151, 27

Leardini, R.; McNab, H.; Minozzi, M. \& Nanni, D. (2001). J. Chem. Soc., Perkin Trans. 1, 1072

Le Tadic-Biadatti, M.-H.; Callier-Dublanchet, A.-C-; Horner, J. H.; Quiclet-Sire, B.; Zard, S. Z. \& Newcomb, M. (1997). J. Org. Chem., 62, 559

McCarroll, A. J. \& Walton, J. C. (2000). J. Chem. Soc., Perkin Trans. 2, 2399

Mikami, T. \& Narasaka, K. (2000). Chem. Lett., 338

Mikami, T. \& Narasaka, K. (2001). C. R. Acad. Sci. Paris, Chimie/Chemistry, 4, 477

Mukai, T.; Oine, T. \& Matsubara, A. (1969). Bull. Chem. Soc. Japan, 42, 581

Nanni, D.; Calestani, G.; Leardini, R. \& Zanardi, G. (2000). Eur. J. Org. Chem., 707

Newman, H. (1968a). Tetrahedron Lett., 2417

Newman, H. (1968b). Tetrahedron Lett., 2421

Ogata, M.; Kano, H. \& Matsumoto, H. (1968). Chem. Commun., 397

Okada, T.; Kawanisi, H. \& Nozaki, H. (1969). Bull. Chem. Soc. Japan, 42, 2981

Padwa, A. \& Albrecht, F. (1974a). J. Org. Chem., 36, 2361

Padwa, A. \& Albrecht, F. (1974b). J. Am. Chem. Soc., 96, 4849

Padwa, A. (1977). Chem. Rev., 77, 37

Pace, A.; Buscemi, S.; Vivona, N.; Silvestri, A. \& Barone, G. (2006). J. Org. Chem., 71, 2740

Petrucci, R. H.; Herring, F. G.; Madura, J. D. \& Bissonnette, C. (2011). General Chemistry: Principles and Modern Applications (10th edition), Chapter 10, p 435, Pearson Canada Inc., Toronto, Canada

Pinter, B.; DeProft, F.; VanSpeybroeck, V.; Hemelsoet, K.; Waroquier, M.; Chamorro, E.; Veszpremi, T. \& Geerlings, P. (2007). J. Org. Chem., 72, 348

Portela-Cubillo, F.; Scanlan, E. M.; Scott, J. S. \& Walton, J. C. (2008). Chem. Commun., 4189

Portela-Cubillo, F.; Alonso-Ruiz, R.; Sampedro, D. \& Walton, J. C. (2009). J. Phys. Chem., 113, 10005

Pratt, A. C. (1977). Chem. Soc. Rev., 6, 63

Renaud, P. \& Sibi, M. P. (Eds.). (2001). Radicals in Organic Synthesis, Wiley-VCH, Weinheim, Germany 
Roberts, B. P. \& Winter, J. N. (1979). J. Chem. Soc., Perkin Trans. 2, 1353

Rosa, A. M.; Lobo, A. M.; Branco, P. S.; Prabhabar, S. \& Sá-da-Costa, M. (1997). Tetrahedron, 53,299

Sakuragi, H.; Ishikawa, S.-I-; Nishimura, T.; Yoshida, M.; Inamoto, N. \& Tokumaru, K. (1976). Bull. Chem. Soc. Japan, 49, 1949

Sauer, J. \& Mayer, K. K. (1968). Tetrahedron Lett., 325

Servais, A.; Azzouz, M.; Lopes, D.; Courillon, C. \& Malacria, M. (2007). Angew. Chem. Int. Ed., 46, 576

Takeuchi, H.; Nagai, T. \& Tokura, N. (1972). J. Chem. Soc., Perkin Trans. 2, 420

Togo, H. (2004). Advanced Free Radical Reactions for Organic Synthesis, Elsevier, Oxford, U.K.

Turro, N. J. (1991). Modern Molecular Photochemistry, p 253, University Science Books, Sausalito, U.S.A.

Uchiyama, K.; Hayashi, Y. \& Narasaka, K. (1998). Chem. Lett., 1261

Yoshida, M.; Sakuragi, H.; Nishimura, T.; Ishikawa, S. \& Tokumaru, K. (1975). Chem. Lett., 1125

Zard, S. Z. (2003). Radical Reactions in Organic Synthesis, Oxford University Press, Oxford, U.K.

Zard, S. Z. (2008). Chem. Soc. Rev., 37, 1603 


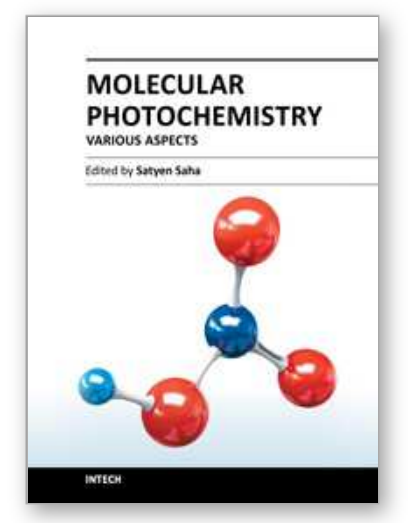

\author{
Molecular Photochemistry - Various Aspects \\ Edited by Dr. Satyen Saha
}

ISBN 978-953-51-0446-9

Hard cover, 282 pages

Publisher InTech

Published online 30, March, 2012

Published in print edition March, 2012

There have been various comprehensive and stand-alone text books on the introduction to Molecular Photochemistry which provide crystal clear concepts on fundamental issues. This book entitled "Molecular Photochemistry - Various Aspects" presents various advanced topics that inherently utilizes those core concepts/techniques to various advanced fields of photochemistry and are generally not available. The purpose of publication of this book is actually an effort to bring many such important topics clubbed together. The goal of this book is to familiarize both research scholars and post graduate students with recent advancement in various fields related to Photochemistry. The book is broadly divided in five parts: the photochemistry I) in solution, II) of metal oxides, III) in biology, IV) the computational aspects and V) applications. Each part provides unique aspect of photochemistry. These exciting chapters clearly indicate that the future of photochemistry like in any other burgeoning field is more exciting than the past.

\title{
How to reference
}

In order to correctly reference this scholarly work, feel free to copy and paste the following:

Miguel A. Rodríguez (2012). Light-Induced Iminyl Radicals: Generation and Synthetic Applications, Molecular Photochemistry - Various Aspects, Dr. Satyen Saha (Ed.), ISBN: 978-953-51-0446-9, InTech, Available from: http://www.intechopen.com/books/molecular-photochemistry-various-aspects/light-induced-iminyl-radicalsgeneration-and-synthetic-applications

\section{INTECH}

open science | open minds

\author{
InTech Europe \\ University Campus STeP Ri \\ Slavka Krautzeka 83/A \\ 51000 Rijeka, Croatia \\ Phone: +385 (51) 770447 \\ Fax: +385 (51) 686166 \\ www.intechopen.com
}

\author{
InTech China \\ Unit 405, Office Block, Hotel Equatorial Shanghai \\ No.65, Yan An Road (West), Shanghai, 200040, China \\ 中国上海市延安西路65号上海国际贵都大饭店办公楼 405 单元 \\ Phone: +86-21-62489820 \\ Fax: $+86-21-62489821$
}


(C) 2012 The Author(s). Licensee IntechOpen. This is an open access article distributed under the terms of the Creative Commons Attribution 3.0 License, which permits unrestricted use, distribution, and reproduction in any medium, provided the original work is properly cited. 